\title{
Badanie charakterystyk statycznych i dynamicznych układu źródło zasilania - łuk
}

\section{Output static and dynamic characteristics of welding power source-arc systems}

\section{Streszczenie}

Każda metoda spawania łukowego ma swoją specyfikę, wynikającą z zakresu stosowanych parametrów, właściwości łuku (składu chemicznego przestrzeni łukowej, rodzaju elektrody itp.) oraz sposobów przechodzenia metalu w łuku, a tym samym stwarza inne wymagania dotyczące zarówno właściwości statycznych, jak i dynamicznych spawalniczych źródeł zasilania. W artykule przedstawiono wybrane zagadnienia z zakresu badania charakterystyk użytkowych urządzeń spawalniczych, będące efektem dotychczasowych prac oraz perspektywy dalszych badań.
Abstract

Arc welding methods differ from one another due to the range of process parameters used, properties of the arc determinated by the chemical composition of arc column, type of electrode as well as the mode of metal transfer. These conditions influence some specific requirements to be fulfilled by power sources used for each arc welding process. Some aspects concerning determination of output static and dynamic characteristics of welding power source and power source-arc system are presented.

\section{Wstęp}

Spawanie łukowe wymaga dostarczenia znacznych ilości energii cieplnej w krótkim czasie. W przewodniku elektrycznym ciepło wydzielane jest na skutek przepływu prądu $i$ jest proporcjonalne do kwadratu jego wielkości, zgodnie z prawem Joule'a: $Q=R \times R^{2} \times t$. Dwukrotne zmniejszenie prądu powoduje czterokrotne zmniejszenie wydzielanego ciepła. Moc elektryczna, wyrażana jako iloczyn napięcia i prądu $P=U \times I$, przesyłana jest przy wysokim napięciu i niskim prądzie, właśnie ze względu na minimalizację strat na ciepło. Proces spawania wymaga $z$ kolei odwrotnej relacji: wysokiego prądu przy niskim napięciu w celu maksymalizacji wydzielanego ciepła.

Zadanie dopasowania prądu i napięcia do potrzeb procesu pełnią zasilacze spawalnicze, które $z$ tego

Mgr inż. Krzysztof Skrzyniecki, dr hab. inż. Andrzej Kolasa, prof. nzw. PW, dr inż. Paweł Cegielski - Politechnika Warszawska. względu są przekształtnikami elektrycznymi. Zasilane z sieci sinusoidalnym napięciem jednofazowym $230 \mathrm{~V}$ lub trójfazowym $380 \mathrm{~V}$ pobierają prąd rzędu od kilkunastu do kilkudziesięciu amperów, generują natomiast stały lub przemienny prąd o wartości kilkuset amperów przy napięciu od kilku do kilkudziesięciu woltów. W obwodzie spawalniczym, na który składają się: łuk elektryczny, elektroda, łączone elementy, przewody oraz urządzenie spawalnicze, pełnią funkcję źródła, stąd często używane określenie spawalnicze źródło energii elektrycznej.

Taki stopień uogólnienia wydaje się w pełni zrozumiały, jeżeli weźmie się pod uwagę dużą różnorodność konstrukcji urządzeń spawalniczych. Producenci dzielą je wg przeznaczania, tj. do określonego procesu spawania: elektrodą otuloną, TIG, MIG, MAG, łukiem krytym itd. Różnią się one wyposażeniem (osprzętem), lecz zastosowane w nich zasilacze energii elektrycznej mają często taką samą konstrukcję, zasadę działania, takie same lub nastawiane (regulowane) rodzaje charakterystyk, czy rodzaje prądu spawania.

Każda metoda spawania łukowego ma swoją specyfikę, wynikającą z zakresu stosowanych parametrów, właściwości łuku (składu chemicznego 
przestrzeni łukowej, rodzaju elektrody itp.) oraz sposobów przechodzenia metalu w łuku, a tym samym stwarza inne wymagania dotyczące zarówno właściwości statycznych, jak i dynamicznych spawalniczych źródeł zasilania. W artykule przedstawiono wybrane zagadnienia z zakresu badania charakterystyk statycznych i dynamicznych układu źródło zasilania - łuk, w różnych metodach spawania, będące efektem dotychczasowych prac autorów oraz perspektywy dalszych badań $[2,3,6,7]$.

Przedstawione wyniki otrzymano w ramach pracy naukowej finansowanej ze środków budżetowych na naukę w latach $2010-2013$ jako projekt badawczy [5].

\section{Zewnętrzne charakterystyki statyczne}

W obwodzie elektrycznym można wyróżnić dwa typy źródeł:

- idealne źródło prądu - wymuszające określony przebieg prądu (np. stały lub sinusoidalny) niezależnie od podłączonego obciążenia; napięcie jest wielkością wynikową zależną od właściwości odbiornika:

- idealne źródło napięcia - wymuszające określony przebieg napięcia (np. stały lub sinusoidalny) niezależnie od podłączonego obciążenia; przepływ prądu jest wielkością wynikową.

W praktyce idealnych źródeł nie ma. W sieci energetycznej 230 V występują obniżenia napięcia w przypadku nagłego wzrostu obciążenia, np. przy jednoczesnym włączeniu wielu odbiorników. Jest to podobne zjawisko do spadku napięcia akumulatora samochodowego podczas rozruchu, gdy jest on znacznie obciążony. Zdolność do utrzymywania parametrów pomimo wzrostu obciążenia określana jest jako sztywność

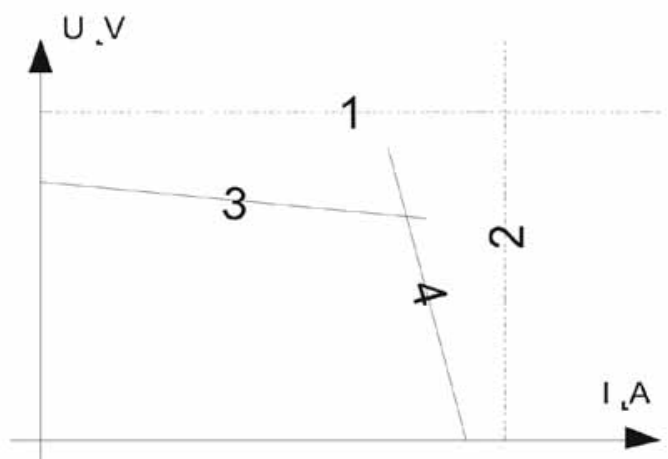

Rys. 1. Schematyczne przedstawienie poszczególnych typów zewnętrznych charakterystyk statycznych spawalniczych źródeł energii Fig. 1. Schematic presentation of output static volt-ampere characteristics of arc welding power sources źródła. Podobnie zachowuje się większość źródeł, w tym szczególnie spawalnicze źródła energii, których nominalne warunki obciążenia zbliżone są do stanu zwarcia, gdyż wypadkowa rezystancja obwodu spawalniczego jest niewielka.

Do opisu właściwości źródła może być zastosowana jego zewnętrzna charakterystyka statyczna, przedstawiająca wzajemną relację napięcia i prądu przy zmieniającym się obciążeniu (rys. 1) [4]: idealna charakterystyka napięciowa (1), idealna charakterystyka prądowa (2), charakterystyka opadająca - źródło o charakterystyce napięciowej (3), źródło o charakterystyce prądowej (4).

Idea pomiaru charakterystyki statycznej jest prosta. Badane źródło obciążane jest stopniowo zmniejszaną rezystancją, rejestrowane są przy tym wartości prądu i oraz napięcia $\mathrm{u}$, które naniesione na wykres $u(i)$ tworzą charakterystykę statyczną badanego źródła (rys. 2). Dla zasilania stałego odczytywana jest jego
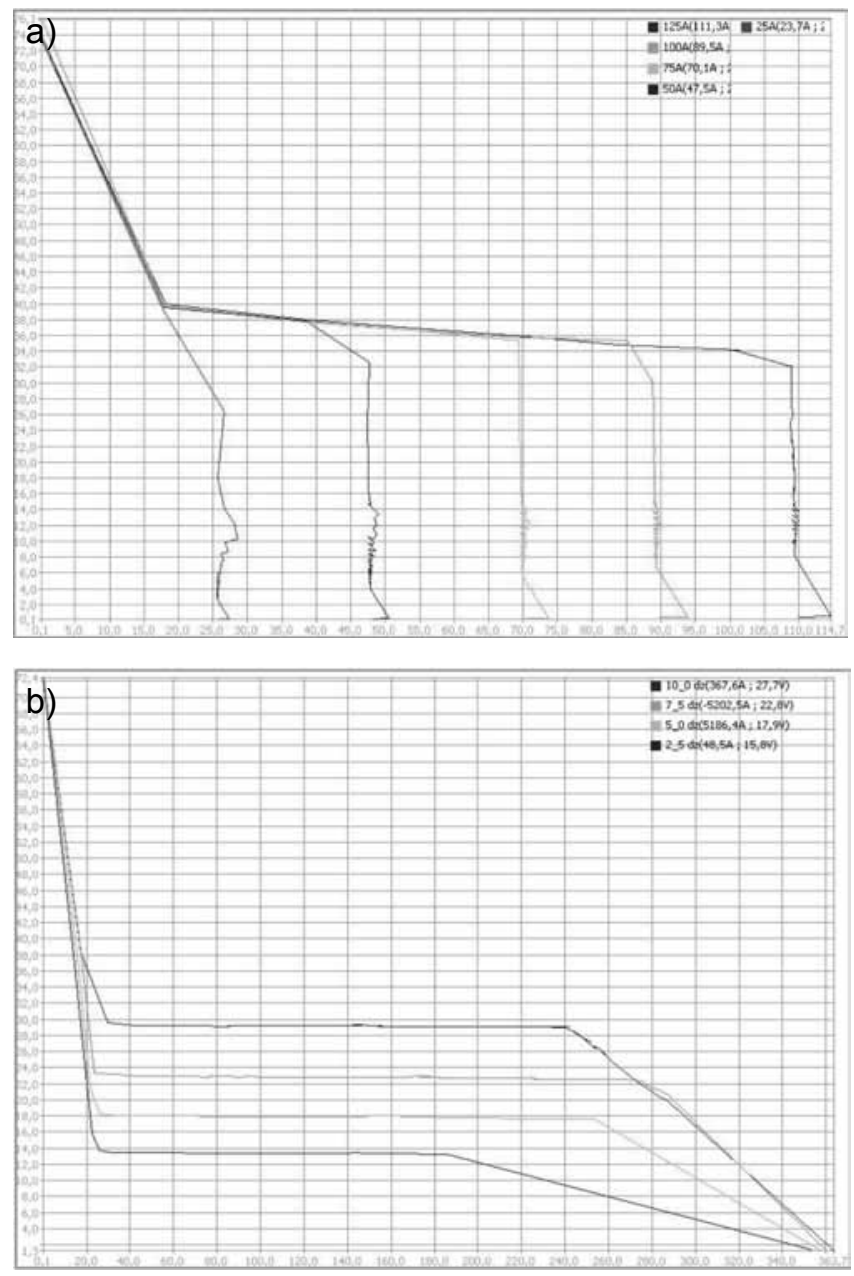

Rys. 2. Przykładowe charakterystyki statyczne uzyskane przy wykorzystaniu opracowanego systemu pomiarowego: a) zasilacz do spawania metodą TIG i elektrodą otuloną (źródło prądu), b) zasilacz MIG/MAG (źródło napięcia)

Fig. 2. An example of output static characteristics registered with the use of designed measuring system for: a) power source for TIG and MMA process with current characteristic, b) power source for MIG/MAG process with voltage characteristic 
wartość aktualna, natomiast dla zasilania przemiennego (sinusoidalnego lub innego) wartość skuteczna. Wartość skuteczna (RMS) jest to stały odpowiednik danego sygnału niosący taką samą ilość energii.

Praktyczne wykonanie pomiarów charakterystyki jest jednak utrudnione ze względu na specyfikę procesu. Rezystancja obciążenia powinna odpowiadać sumarycznej rezystancji obwodu spawalniczego, a więc zawierać się w zakresie od kilku omów do zera, czyli zwarcia. Ilość energii wydzielonej w postaci ciepła odpowiada energii wydzielonej podczas spawania, powinna być więc wystarczająco szybko odprowadzana, aby nie dopuścić do uszkodzenia obciążenia. Dodatkowo, rezystancja przewodników zmienia się wraz ze wzrostem temperatury, która powinna pozostawać na stałym poziomie.

W ramach badań prowadzonych w Zakładzie Inżynierii Spajania PW powstało nowatorskie urządzenie do pomiaru charakterystyk statycznych [2]. Istota jego działania polega na automatycznie sterowanym obciążeniu rezystancyjnym, przełączanym elektronicznie za pomocą kluczy tranzystorowych IGBT, przy jednoczesnej rejestracji wszystkich mierzonych parametrów, takich jak prąd, napięcie, a nawet emisja akustyczna łuku spawalniczego lub źródła. Zarówno zadawanie kolejnych wartości obciążenia, jak i pomiar oraz rejestracja mierzonych parametrów wyjściowych badanego zasilacza spawalniczego realizowane są przez nadzorujący pracę stanowiska komputerowy system pomiarowo-sterujący.

W przypadku urządzeń transformatorowych oraz prostownikowych charakterystyka statyczna zależy od konstrukcji urządzenia, zastosowanych rozwiązań technicznych, wykorzystanych komponentów i materiałów (np. blach transformatorowych) oraz jakości wykonania (np. dokładności nawinięcia uzwojeń). W przypadku urządzeń inwertorowych sytuacja jest bardziej złożona. Oprócz wymienionych czynników, charakterystyk tranzystorów oraz modulacji
PWM znaczny, a nawet decydujący wpływ ma układ sterowania i zawarte w nim algorytmy. Urządzenia te z łatwością spełniają dotychczasowe wymagania dotyczące charakterystyk statycznych, a nawet umożliwiają implementację wielu dodatkowych funkcji, dzięki możliwości programowania charakterystyk statycznych. Przykładowo, ograniczenie wartości prądu podczas zwarcia ułatwia pracę i zapobiega przyklejeniu elektrody. Dzięki temu proces spawania jest łatwiejszy i możliwy do wykonania nawet przez mniej doświadczonego pracownika. Jak widać, pojawia się konieczność opracowania nowych metod badania i oceny urządzeń oraz ich właściwości.

\section{Charakterystyki dynamiczne}

Charakterystyki dynamiczne spawalniczych źródeł energii można podzielić na dwie kategorie. Pierwsza opiera się kontrolowanej zmianie obciążenia według zadanej sekwencji - badana jest m.in. odpowiedź źródła na skok jednostkowy obciążenia. Funkcja sterowania obciążeniem realizowana jest za pomocą opisanego wcześniej urządzenia do pomiaru charakterystyk statycznych. Dzięki możliwości zaprogramowania pożądanego przebiegu i wygenerowania sekwencji sterującej obciążeniem pomiar odbywa się w pełni automatycznie bez ingerencji operatora (rys. 3). Odpowiedź na skok jednostkowy dostarcza informacji o dynamice badanego obiektu, m.in. czasie reakcji na zmianę oraz czasie do osiągnięcia stanu ustalonego.

Druga kategoria obejmuje pomiary przebiegów prądu i napięcia podczas spawania prowadzonego w kontrolowanych warunkach (rys. 4). Pomiar odbywa się na w pełni skonfigurowanym stanowisku spawalniczym. Jedyną modyfikacją jest włączenie w obwód spawalniczy urządzenia pomiarowego umożliwiającego rejestrację prądu i napięcia.

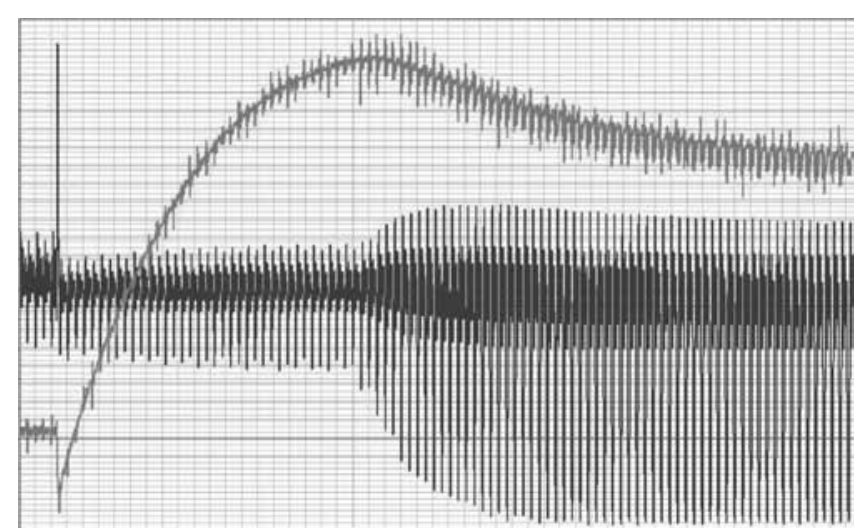

Rys. 3. Przykładowa charakterystyka dynamiczna uzyskana przy sterowanym obciążeniu

Fig. 3. An example of dynamic characteristics registered for controlled load

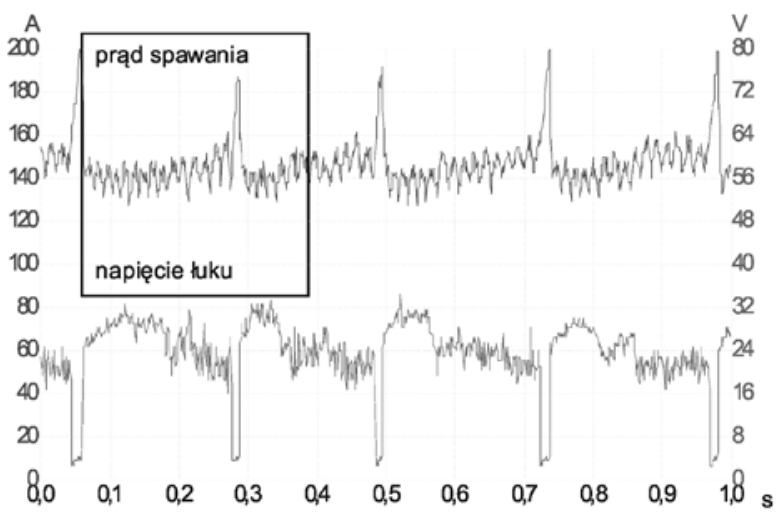

Rys. 4. Przykładowa charakterystyka dynamiczna uzyskana podczas spawania elektrodą otuloną

Fig. 4. An example of volt-ampere dynamic characteristics registered during MMA welding process 


\section{Podsumowanie}

Na rynku są dostępne różne urządzenia do pomiarów parametrów spawania. Oprócz rejestracji prądu i napięcia umożliwiają monitorowanie posuwu drutu elektrodowego czy wydatku gazów osłonowych. Jednak analiza zarejestrowanych przebiegów oraz ich interpretacja jest nadal trudna i niejednoznaczna.

Celem badań prowadzonych w Zakładzie Inżynierii Spajania PW jest poznanie relacji pomiędzy zmianami parametrów elektrycznych obwodu spawalniczego a zjawiskami zachodzącymi podczas spawania i mającymi wpływ na ostateczne cechy złącza. Stąd też konieczność dostosowania urządzeń pomiarowych do specyfiki badań.

Ideą rozpoczętych badań jest analiza obwodu spawalniczego pod kątem jego parametrów elektrycznych, takich jak rezystancja, indukcyjność i pojemność, dynamicznie zmieniających się w czasie procesu spawania. Pomiar tych wielkości w stanie ustalonym jest stosunkowo prosty, natomiast dynamika procesu znacząco utrudnia badania. Do ich wyznaczenia posłużą metody modelowania, a szczególnie identyfikacji obiektów dynamicznych stosowane m.in. w automatyce oraz $w$ analizie obwodów elektrycznych [1]. Uzyskane wyniki pomiarów zostaną skonfrontowane $z$ wynikami badań właściwości mechanicznych złączy w celu określenia wzajemnych relacji.

\section{Literatura}

[1] Bolkowski S.: Teoria obwodów elektrycznych, WNT, Warszawa 2003.

[2] Cegielski P., Kolasa A.: Komputerowy system do badań właściwości statycznych i dynamicznych spawalniczych źródeł energii elektrycznej. Prace Naukowe Politechniki Warszawskiej, z. 215, Mechanika, Warszawa 2006.

[3] Kolasa A., Cegielski P., Węglowski M., Skrzyniecki K.: Technical Performance of Low Power Welding Inverters. IV'th International Conf. on Advanced in Production Engineering APE'2007, Warsaw University of Technology, Warsaw 2007.

[4] PN-EN 60974-1:2007 Sprzęt do spawania łukowego. Część 1: Spawalnicze źródła energii.

[5] Projekt badawczy własny Ministra Nauki i Szkolnictwa Wyższego nr N N503 206339 pt. Badanie zależności pomiędzy zjawiskami zachodzącymi w łuku spawalniczym w różnych odmianach metody MAG a parametrami elektrycznymi układu łuk-urządzenie spawalnicze. (kier.: prof. A. Kolasa).

[6] Węglowski M., Kolasa A., Cegielski P.: Badania właściwości technologicznych spawalniczych zasilaczy inwertorowych. Przegląd Spawalnictwa, 9-10/2006.

[7] Węglowski M., Kolasa A., Cegielski P.: Ocena stabilności procesu ręcznego spawania łukowego elektrodami otulonymi. Przegląd Spawalnictwa, 1/2006.

\section{Zapowiedź wydawnicza}

Lechosław Tuz, Paweł Kołodziejczak, Andrzej Kolasa

\section{Struktura złączy doczołowych odlewniczych stopów magnezu}

\section{Streszczenie}

W artykule przedstawiono ocenę struktury złączy odlewniczych stopów magnezu, wykonanych trzema metodami spajania: zgrzewaniem tarciowym z mieszaniem materiału zgrzeiny (FSW), spawaniem laserowym przy zastosowaniu lasera $\mathrm{CO}_{2}$ oraz spawaniem łukowym w osłonie gazu obojętnego elektrodą nietopliwą (TIG). Oceniano makro i mikrostrukturę złączy doczołowych przy zastosowaniu mikroskopu optycznego z układem cyfrowej rejestracji obrazu.

Do badań zastosowano dwa stopy magnezu AZ91 i AM-Lite, w których cynk i aluminium stanowią główne dodatki stopowe. Materiał wyjściowy stanowiły gąski odlewnicze, które sfrezowano na określony wymiar a następnie wycięto płaskowniki o grubości $3 \mathrm{~mm}$.

Przeprowadzona ocena wykazała, że możliwe jest uzyskanie złączy ze stopów magnezu o wysokiej jakości. Odnotowano jednak śladowe ilości porów w obszarze złącza. 